\section{IMF Working Paper}

(C) 1997 International Monetary Fund
This is a Working Paper and the author(s) would welcome any comments on the present text. Citations should refer to a Working Paper of the International Monetary Fund. The views expressed are those of the author(s) and do not necessarily represent those of the Fund.

WP/97/46

INTERNATIONAL MONETARY FUND

Fiscal Affairs Department

\title{
The Effect of Expected Effective Corporate Tax Rates on Incremental Financing Decisions
}

Prepared by Reint E. Gropp ${ }^{1}$

Authorized for distribution by Liam P. Ebrill

April 1997

\begin{abstract}
This paper uses U.S. panel data to estimate the effect of expected effective corporate tax rates on firm's leverage. The paper directly estimates expected corporate tax rates using rational expectations. The estimated measures of the expected effective tax rates of firms are related to a continuous measure of incremental debt financing. The paper finds that expected effective tax rates are significantly and positively related to a higher level of debt financing. Simulations suggest that debt issues would double if firms were unable to shield profits and actually faced the statutory tax rate.
\end{abstract}

JEL Classification Numbers: H25, H32, G32

Author's E-Mail Address: RGropp@IMF.org

${ }^{1}$ This paper is based on Chapter 3 of my Ph.D. dissertation. I would like to thank John Karl Scholz, James Andreoni, and especially, David Mauer, for valuable comments and suggestions. 


\section{CONTENTS}

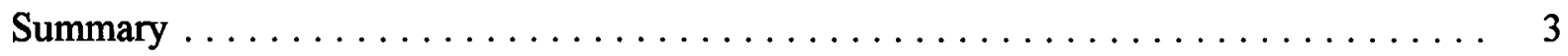

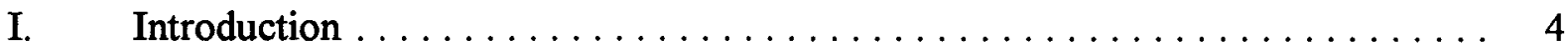

II. Estimation of Expected Effective Corporate Tax Rates $\ldots \ldots \ldots \ldots \ldots$

A. Determinants of Future Effective Tax Rates $\ldots \ldots \ldots \ldots \ldots \ldots \ldots$

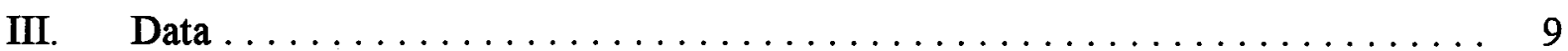

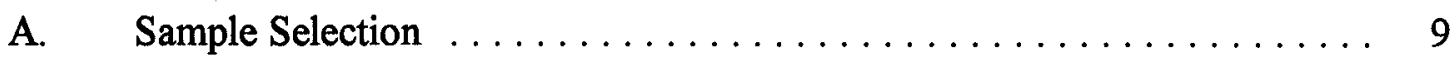

B. Other Data Considerations $\ldots \ldots \ldots \ldots \ldots \ldots \ldots \ldots \ldots \ldots \ldots$

IV. Estimated Effective Tax Rates $\ldots \ldots \ldots \ldots \ldots \ldots \ldots \ldots \ldots$

V. Estimation of Financing Decisions $\ldots \ldots \ldots \ldots \ldots \ldots \ldots \ldots$

VI. Other Theories of Capital Structure Choice $\ldots \ldots \ldots \ldots \ldots \ldots$

VII. Estimation Results for Firms' Financing Decisions $\ldots \ldots \ldots \ldots \ldots \ldots$

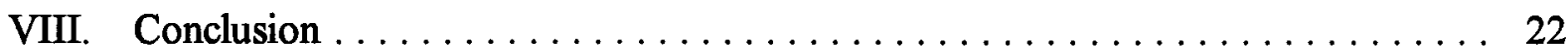

Tables

1. Estimation of Effective Tax Rates $\ldots \ldots \ldots \ldots \ldots \ldots \ldots \ldots$

2. Expected Tax Rates and Financing Decisions $\ldots \ldots \ldots \ldots \ldots \ldots \ldots$

3. Probit and Unbalanced Panel Results $\ldots \ldots \ldots \ldots \ldots \ldots \ldots \ldots \ldots \ldots \ldots$

\section{Appendices}

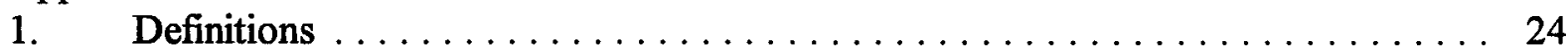

2. Summary Statistics . . . . . . . . . . . . . . . . . . . 26

3. Additional Results for the Estimation of Expected Tax Rates . . . . . . . . 27

4. Additional Results for the Financing Decision . . . . . . . . . . . . . . 29

References ............................... 31 


\section{SUMMARY}

Corporate taxation in the United States currently treats debt and equity financing of firms differently. Interest payments, unlike dividends, are deducted from the corporate income tax and, therefore, enjoy a tax advantage. Firms with higher corporate tax rates have an incentive to increase leverage. Although most firms face the same statutory tax rate, effective corporate tax rates may vary greatly because of differences in the ability to shield profits from the corporate tax. A firm with higher investment tax credits, accelerated depreciation allowances, or tax loss carryforwards can be expected to have lower effective corporate tax rates than an identical firm without these nondebt tax shields.

This paper uses U.S. panel data (Compustat) to estimate the effect of expected effective corporate tax rates on firm's leverage. The previous literature has focused on relating proxies for future effective tax rates to financing ratios of firms. In this paper, expected effective corporate tax rates are estimated directly using a rational expectations approach. Several firmspecific expected effective tax rates are calculated, based on different assumptions about the time horizon of firms. The methodology allows one to test the quality of the proxies for future effective tax rates used in the previous literature. Current effective tax rates, investment tax credits, and depreciation expenses are found to be powerful predictors of lower future effective tax rates.

The estimated measures of expected effective tax rates of firms, are then related to a continuous measure of incremental debt financing. The results indicate that the rates are significantly and positively related to a higher level of debt financing, which supports the tax hypothesis, controlling for a large number of other theories of capital structure choice. Simple simulations suggest that debt issues would double if firms were unable to shield profits and actually faced the statutory tax rate on all profits. 


\section{INTRODUCTION}

The current system of corporate taxation in the United States treats debt and equity financing of firms differently. Interest payments, unlike dividends, are deducted from the corporate income tax and, therefore, enjoy a tax advantage. Firms with higher corporate tax rates have an incentive to increase leverage. Although most firms face the same statutory tax rate, effective corporate tax rates may vary greatly because of differences across firms in the ability to shield profits from the corporate tax. ${ }^{2} \mathrm{~A}$ firm with higher investment tax credits, accelerated depreciation allowances, or tax loss carryforwards face lower effective corporate tax rates than an identical firm without these nondebt tax shields.

A large number of studies attempt to empirically establish the relationship between nondebt tax shields and financing choices of firms. Titman and Wessels (1988), Bradley, Jarrell, and Kim (1984) among others, fail to find significant tax effects. MacKie-Mason (1990a) shows that it is important to consider incremental financing decisions, rather than aggregate debtequity ratios. If effective tax rates of firms change over time, aggregate debt-equity ratios are the result of financing decisions made with different tax incentives. He relates tax loss carryforwards to the probability of issuing debt versus equity given that the firm chooses to use external financing and finds that firms with more tax loss carryforwards and, hence, lower expected effective tax rates are significantly less likely to issue debt. This finding supports the tax hypothesis of capital structure choice.

MacKie-Mason's approach has two major shortcomings. The sample is limited to firms that issue either debt or equity publicly and, hence, does not consider the full menu of financing available to each firm. ${ }^{3}$ In addition the discrete choice approach discards valuable information about the magnitude of debt or equity issues. Both shortcomings make the obtained coefficients difficult to interpret. ${ }^{4}$

The previous literature has focused on relating proxies for expected corporate tax rates to firms' financing choices without explicitly testing the quality of their tax proxies. In this paper explicit behavioral assumptions are made about the process governing the formation of

\footnotetext{
${ }^{2}$ Income up to $\$ 100,000$ is taxed at a lower rate, which generally only concerns very small firms. This feature of the corporate tax system is ignored throughout this paper.

${ }^{3}$ Bond and stock issues, as well as bank loans and retained earnings compose the full choice menu of the firm.

${ }^{4}$ Gentry (1994) compares the capital structure decision of publicly traded partnerships and corporations in the U.S. oil and gas exploration industries. He finds that partnerships, which are not subject to the corporate income tax, are significantly less likely to use debt financing, which provides support for the tax hypothesis. His estimates, however, only apply to one industry and cannot be generalized to reach conclusions about the whole population of firms in the U.S. Gropp (1995) uses variation of local business tax rates in Germany and finds that taxes have a significant effect on the capital structure choice of German firms.
} 
expectations of firms. This approach provides a direct test of the effect of the proxies used in the previous literature on the expected corporate tax rate. The paper uses a two step approach. First, expected effective corporate tax rates are estimated using information about current tax loss carryforwards, investment tax credits, and current effective tax rates, as well as other observable firm characteristics. In the second stage, this measure is related to firms' incremental financing choice.

In addition the paper attempts to address some of the other shortcomings of the previous literature by considering all financing choices available to the firm, as well as by estimating tax coefficients for a sample containing all major manufacturing firms, regardless of their financial decisions or industry. Estimated expected tax rates are found to have a substantial effect on the choice between debt and equity of firms in all specifications. Factors influencing effective corporate tax rates, like statutory tax rates, the magnitude of investment tax credits, and accelerated depreciation allowances are likely to have at least a moderately large effect on the supply of debt and equity by firms and, hence, on capital markets.

\section{ESTIMATION OF EXPECTED EFFECTIVE CORPORATE TAX RATES}

Although the corporate income tax is generally a flat tax, even firms with identical profits in a given period might face different effective tax rates. Firms are allowed to carry profits and losses forward as well as backward to smooth their tax burden over time. ${ }^{5}$ Moreover, some firms might benefit from investment tax credits or accelerated depreciation allowances, which tend to decrease effective tax rates. By the same token, firms' expectations about future tax payments depend on past profits, as well as on future and current investment tax credits, and future extraordinary expenses (discontinued operations).

There have been several different attempts to model firms' ability to shield profits and the resulting effective tax rates. Bradley, Jarrell, and Kim (1984) calculate the 20 year average of annual depreciation plus investment tax credits divided by average earnings. The authors regress this proxy of firms' effective tax rates on the firms' debt-to-value ratio and find a significantly positive coefficient which is taken as evidence against the tax hypothesis of capital structure choice. (Titman and Wessels (1988) in a more elaborate empirical model, but with a similar measure, find insignificant tax effects.)

MacKie-Mason [1990a] points out that investment tax credits might not be a good predictor of lower future effective tax rates because they might be positively correlated with more profitable investment opportunities. Firms with more profitable investment opportunities, however, are less likely to be tax exhausted. This reasoning might explain Bradley, Jarrell, and Kim's (1984) estimated positive and significant relationship between investment tax credits

${ }^{5}$ See Auerbach and Poterba (1987) and Altshuler and Auerbach (1990) for more institutional details about tax loss carryforwards and their effect on the effective corporate tax rates of firms. 
and debt financing. MacKie-Mason (1990a) attempts to address this problem by interacting investment tax credits with a measure of the firms' likelihood of tax exhaustion (Altman's (1968) bankruptcy predictor) and finds the expected negative and significant effect. In addition, the author proposes tax loss carryforwards as a variable that will unambiguously indicate lower future tax rates and finds that firms with tax loss carryforwards are significantly less likely to issue debt. This is evidence in favor of the tax hypothesis of capital structure choice.

This paper extends the approach taken by MacKie-Mason in that the effect of tax shields on future tax rates is explicitly modeled. Using U.S. panel data, we estimate several measures of expected taxes under different assumptions about the process of expectation formation of the firm. This approach affords a direct test of the effect of the proxies used by previous authors on future effective tax rates.

Previous studies have assumed that the financing and investment decisions of firms are independent (see; for example, MacKie-Mason (1990a), Gentry (1994)). ${ }^{6}$ The same approach is adopted here and firms are assumed to follow a two step decision process. Specifically, in each period, firms make an investment decision first. Given this investment, firms decide how to finance it and also whether to adjust their capital structure. Firms can adjust their capital structure by issuing debt to repurchase shares, or by issuing equity to retire debt. In each period, firms form expectations about the discounted present value of the tax payments in each future period associated with the returns generated by the new investments, given their information set at time $t$. This can be written as

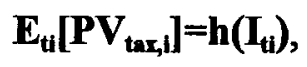

where $P V_{\text {tax, }}$ represents the discounted present value of the tax payments of the investments of firm $i$ at time $t, E$ is the expectations operator and $I_{t}$ denotes the information set of firm $i$ at time $t$.

It is not possible to calculate $\mathrm{PV}_{\mathrm{tax}, \mathrm{i}}$ directly, because one does not have information on the firms' individual investment projects, their returns, and associated tax payments. Hence, four different proxies are proposed that are calculated on the basis of different assumptions about the rate at which the firm discounts the future. All proxies are estimated using a simple rational expectations approach. First, the firm is assumed to only look one period into the future and we present two consistent estimators for that case. Second, firms are assumed to have a horizon of five years. Two estimators are presented for that case as well. Each model is discussed in turn.

\footnotetext{
${ }^{6}$ This appears to be a reasonable assumption. Recently, Mauer and Triantis (1994) developed a model that suggests the feedback effects between financing and investment decisions are likely to be small.
} 
Model I: Actual One-Period Ahead Tax Rates. Kennan (1979) shows that under the assumption of rational expectations the actual value can be used as a proxy of the expectation. Hence, the actual effective corporate tax rate of firm $i$ in period $t+1, \tau_{t+1, i}$ can be used as a proxy for the expected effective corporate tax rate, $\mathrm{E}_{\mathrm{t} i}\left[\tau_{t+1, i}\right]$, and under the additional assumption that firms assign a discount factor of $\infty$ to all periods after $t+1, \tau_{t+1, i}$ is also a proxy for $E_{\mathrm{ti}}\left[\mathrm{PV}_{\mathrm{tax}, \mathrm{i}}\right]^{7}$

Model II: Linear Prediction of One-Period Ahead Tax Rates. Alternatively, in order to obtain $\mathrm{E}_{\mathrm{t} i}\left[\tau_{t+1, \mathrm{i}}\right]$ a simple linear projection can be used. ${ }^{8}$ Holden, Peel, and Thomson (1985) show that consistent estimates of the expected effective corporate tax rates, given the information available to firm $i$ at time $t$, can be obtained by using the predicted values from the estimating equation

$$
\tau_{t+1 i}=\alpha_{0}+\alpha_{i}+\alpha_{t}+\alpha_{1} \tau_{t i}+\alpha_{2} X_{t i}+\eta_{t i}
$$

with $\left|\alpha_{1}\right|<1$ to ensure stationarity. The effective corporate tax rates in period $t+1$ for firm $i$ is denoted by $\tau_{t+1, i}, X_{t i}$ represents the vector of variables in the information set of firm $i$ at time $t$. The specification allows for effects across time and firms.

Hsiao (1986) shows that the estimated parameters obtained from a two-factor fixed effects estimation of (1) are inconsistent, because a lagged dependent variable appears as one of the explanatory variables and, therefore, $\tau_{\mathrm{ti}}$ and the error term of (1) might be correlated. The magnitude of the problem decreases with the length of the panel (i.e., the number of observations for each firm). In addition, the interpretation of the results from estimating (1) depends upon assumptions about the "endowed" effective tax rate of each firm $i$.

Hsiao (1986) gives a consistent feasible generalized least squares estimator for the case when $\tau_{0 \mathrm{i}}$ is independent of the unobservable firm specific effect, $\alpha_{i}$, where $\tau_{0 \mathrm{i}}$ represents the initial effective tax rate of firm $i$ in period 0 . Intuitively, this estimator implies that the initial observation for each firm $i$ is drawn from some distribution that is common to all firms, and the impact of $\tau_{0 \mathrm{i}}$ on subsequent effective tax rates of the firm gradually diminishes over time and eventually disappears. ${ }^{9}$ Whereas this model and Model I described in the previous section should yield very similar proxies for $\mathrm{E}_{\mathrm{t}}\left[\tau_{t+1, \mathrm{i}}\right]$, Model II has the additional benefit of enabling

${ }^{7}$ This also describes the case when the investment only lasts one period.

${ }^{8}$ This is a "rational" expectations model in the sense that firms use all information available to them to "rationally" predict $\tau_{t+1 \text {. }}$. This does not imply that this will yield a "rational" prediction of $P V_{\text {tax,iv }}$ unless the investment only lasts one period.

${ }^{9}$ Alternatively, one could assume that $\tau_{i 0}$ and $\alpha_{i}$ are correlated. This has the undesirable consequence, however, that each firm $i$ converges to some final tax rate that is primarily characterized by the unobservable effect $\alpha_{\mathrm{i}}$. For further discussion see Hsiao (1986). 
us to test the ability of measures of firms' debt and nondebt tax shields to predict future effective tax rates.

Model III: Linear Prediction of Undiscounted Five-Period Ahead Tax Rates. It is likely that firms, when making decisions concerning long-term financing instruments, form expectations about effective tax rates more than one period into the future. The number of periods is arbitrarily fixed at five. ${ }^{10}$ Consider the case when firms do not discount effective tax rates occurring up to five years into the future and assign a discount factor of $\infty$ to all tax rates at period $t+6$ and beyond. A consistent estimator is then obtained, namely

$$
E_{t i}\left[\sum_{s=1}^{5} \frac{\tau_{t+s, i}}{5}\right]
$$

by using (2) in place of $\mathrm{E}_{\mathrm{t} i}\left[\tau_{t+1, \mathrm{i}}\right]$ in equation (1). The variables contained in the information set of firm $i$ at time $t$ are then regressed on the unweighted average of the actual effective tax rates at $t+1, t+2, \ldots, t+5$ and use the predicted values of this regression. The same specification and explanatory variables as in the previous model are used.

Model IV: Linear Prediction of Discounted Five-Period Ahead Tax Rates. Next consider the case when firms discount tax payments accruing further out into the future more heavily than more current tax payments. Hence, instead of the unweighted average of tax rates proposed above, the following weighted average is used

$$
\frac{\sum_{s=1}^{5} \frac{1}{s} \tau_{t+s, i}}{\sum_{s=1}^{5} \frac{1}{s}}
$$

Expression (3) implies that the discount factor is increasing at a decreasing rate as firms look further into the future. The expression has the additional convenient property that it yields a single tax rate and its coefficient can be easily interpreted. ${ }^{11}$ Expression (3) is used in place of the dependent variable in equation (1). The same econometric methodology and explanatory variables are used as in Model III.

\section{A. Determinants of Future Effective Tax Rates}

It is difficult to completely and accurately account for all variables in firms' information sets. To minimize the arbitrariness of this choice, $\mathrm{X}_{\mathrm{i}}$ of equation (1) includes proxies for effective

\footnotetext{
${ }^{10}$ In the empirical analysis below, three periods ahead yield very similar results.

${ }^{11}$ The weights from expression (3) are .444 for period $t+1, .224$ for period $t+2, .124$ for $t+3$, .114 for $t+4$, and .094 for period $t+5$.
} 
corporate tax rates that previous studies have used (see MacKie-Mason (1990a), Titman and Wessels (1988)).

Tax loss carryforwards are the portion of past losses that can be offset against future profits to decrease effective tax rates. Hence, tax loss carryforwards capture most of the information about the earnings history of the firm that is relevant for future effective tax rates. Tax loss carryforwards (scaled by sales) could be expected to be a predictor of lower future effective tax rates (see also MacKie-Mason, 1990a).

Auerbach and Poterba (1987) find that firms have a low probability of moving from a nontaxable to a taxable state and vice versa. Therefore, current effective tax rates as a predictor of future effective tax rates are used. Firms with currently low tax rates could be expected to also have low future tax rates and expect to find a positive relationship between current and future tax rates.

As described above, previous research has not found the expected negative relationship between investment tax credits and future effective tax rates, because firms with larger investment tax credits might be more profitable and face higher taxes. Controlling for current tax status, a firm with higher investment tax credits (scaled by sales) can be expected to face lower future effective tax rates. In addition, we follow MacKie-Mason (1990a) and interact investment tax credits with Altman's (1968) predictor of bankruptcy. The bankruptcy predictor is also included by itself, since clearly a firm close to bankruptcy can expect to pay lower effective tax rates.

Depreciation (scaled by sales) is another measure of tax shields that might be available to the firm. Firms with large depreciation expenses are more likely to face lower effective tax rates in the future compared to otherwise identical firms with lower depreciation expenses.

If a firm has issued substantial amounts of debt in the past it might face lower effective tax rates, because its high interest payments decrease reported profits. Hence, the debt-total asset ratio is included as an explanatory variable in equation (1).

Finally, following MacKie-Mason (1990a) we include two measures of the variability of the firms' earnings as explanatory variables. The more variable the firms' earnings the more of its profits the firm might be able to shield from taxes by carrying losses forward to offset profits. A negative coefficient is expected on both variables.

\section{DATA}

\section{A. Sample Selection}

This study uses annual firm level Compustat data spanning 1979 to 1991 . The sample includes manufacturing firms (SIC codes 2000 to 4900) traded at either the New York Stock 
Exchange or the American Stock Exchange, that are covered by the Compustat industrial tape. The total sample size is 16,930 for the sample period, which represents 1,300 firms. Some firms do not have any data in some periods, however. To generate a balanced panel all firms with missing years are deleted. ${ }^{12}$ The primary sample has 929 firms with complete data for 13 years, which yields 12,077 observations. For missing values of important variables, firm-specific or industry-specific means are used. ${ }^{13}$ The firms in the sample represent 78 percent (1990, all firms) or 62 percent (1990, for the balanced panel) of the total market value of all firms traded either at the New York Stock Exchange or the American Stock Exchange. ${ }^{14}$

\section{B. Other Data Considerations}

This paper considers the effect of taxes on incremental financing decisions (the change in the level of debt) and therefore the tax rate that most accurately reflects firms' incentives is the marginal effective corporate tax rate. Marginal effective tax rates of the investment projects of firm $i$ in period $t$ are not observed in the data, but rather average effective tax rates are. Therefore the average effective tax rate is used as a proxy for the marginal rate.

Marginal tax rates might differ dramatically from average tax rates for firms reporting a loss and for firms with tax loss carryforwards. The effect of tax loss carryforwards in the empirical specifications is controlled for, but it is impossible to accurately calculate effective tax rates for firms reporting a loss in a given period, because effective tax rates are defined as income tax payments divided by profits before taxes. Effective tax rates for these firms are coded as follows: firms reporting losses, yet with positive tax payments, are coded with the statutory tax rate ( 365 cases). We suspect that the firms reported a small positive profit for tax purposes, but due to differences between financial and tax accounting, reported a loss for financial purposes. ${ }^{15} \mathrm{We}$ assume that the profit reported for tax purposes is taxable at the statutory rate. Firms reporting a loss and receiving a refund are coded with the negative statutory corporate tax rate (1,394 cases). We also assume that these firms have unused tax

\footnotetext{
${ }^{12}$ It simplifies the econometrics considerably to estimate Models II through IV using a balanced panel. Estimating the models for the unbalanced panel and allowing for fixed effects across firms and periods requires the estimation of a large number of additional parameters (see Hsiao, 1986). To assess the sensitivity of the results to the dropped firms, results for Model $I$ are also reported using the unbalanced panel and ordinary least squares with time and industry dummies. These results are reported in Section VII.

${ }^{13}$ Using this method rather than imputing missing values generally increases standard errors of the estimated coefficients.

${ }^{14}$ The total market value of all stocks traded at the NYSE and the AMEX is approximately $\$ 2,961$ billion (1990, Source: Statistical Abstract of the United States, 1992), the market value of all stocks in the unbalanced panel in 1990 was $\$ 2,320$ billion, and in the balanced panel $\$ 1,548$ billion.
}

${ }^{15}$ Other problems arising from differences in tax and financial accounting are discussed below. 
shields, which should be reflected in their effective tax rate. ${ }^{16}$ For all other firms effective tax rates are obtained by dividing actual income tax payments by profits before taxes, interest, and discontinued operations $(15,154$ cases $) .{ }^{17}$

An additional problem arises if a firm has earnings close to zero. In that case even a small tax payment may result in extremely high effective tax rates. This is evident from the maximum of 6,600 percent and the minimum of $-39,000$ percent reported in Appendix II. It is possible that these extremely high or low effective tax rates could have a disproportionate influence on the results. Therefore, the tax variable is split into two variables: a "good" tax rate, which is equal to the effective tax rate if the effective tax rate is between 0 and 1 and 0 otherwise and a "bad" tax rate which is equal to the effective tax rate if the effective tax rate is outside the range of 0 and 1 and 0 otherwise. The primary specifications use this split variable.

Auerbach and Poterba (1987) point out that there might be a large discrepancy between the profits that are reported for financial purposes recorded in the Compustat data, and profits reported for tax purposes, which are not publicly available. The first source of discrepancy arises from differences in depreciation allowances. For the computation of financial profits firms use straight-line depreciation, for tax purposes firms are allowed to include accelerated depreciation allowances. Therefore, profits reported in Compustat will be higher than in the tax returns. Firms' effective tax rates consequently will be lower in Compustat data than for tax purposes, because tax payments are calculated using lower profits. Accelerated depreciation allowances are designed to increase investment by lowering the taxes firms pay on investments. Whereas using the effective tax rate calculated from financial statements, it is possible to capture the incentives intended by the policymaker, the measure is clearly not an accurate reflection of the "true" effective tax rate faced by the firm. This is an important caveat to keep in mind.

A second discrepancy between financial and tax data might arise from the treatment of discontinued operations and other large "extraordinary" write-offs and expenses. Auerbach and Poterba (1987) point out that a firm, by discontinuing an unprofitable operation and writing it off, might report a substantial loss in its financial statement but receives no tax benefit from the transaction. In this case financial profits are lower than the profits reported to the tax authorities, leading to overly high effective tax rates for these firms. Therefore, when calculating effective tax rates, the Compustat variable "discontinued operations" was added back to the profit variable.

\footnotetext{
${ }^{16}$ Fullerton (1984) discusses this problem and reports that in previous studies estimating the effect of effective tax rates on investment, firms with losses were coded with their actual tax payments as proxies for effective tax rates. The approach taken here avoids the large outliers associated with that convention.

${ }^{17}$ Discontinued operations are investments that the firm believes will not generate any return in the future and, therefore, are considered without value to the firm and are depreciated in their entirety for financial purposes. Firms are not allowed to depreciate these items fully for tax purposes. This is discussed below.
} 


\section{ESTIMATED EFFECTIVE TAX RATES}

Results from the first stage estimation of effective future tax rates are presented in Table 1. Although these results are primarily used to generate the predicted values used in the estimation of incremental debt/asset ratios, they are also of independent interest. The estimated coefficients are very similar for all three models. Current effective tax rates are an important predictor of future effective tax rates. An increase in current effective tax rates of 1 percentage point is associated with a 0.48 to 0.68 percentage point increase in future effective tax rates, using the coefficient on the "good" tax rate variable. Appendix III reports results for specifications using a single tax rate. It is evident that if the tax rate is not split the effect of current tax rates on future tax rates would be substantially smaller, which is likely due to the exceptionally high and low tax rates in the sample.

It is surprising that tax loss carryforwards appear to be correlated with higher future effective tax rates when controlling for current tax rates, although the coefficients are very small and insignificant. It appears that tax loss carryforwards do not contain much additional information when controlling for current effective tax rates.

Contrary to MacKie-Mason (1990a), investment tax credits are significantly negatively related to lower effective corporate tax rates. The second measure of nondebt tax shields used, depreciation divided by sales, also is a strong predictor of lower future effective tax rates, despite the fact that the depreciation variable is likely to be incorrectly measured, because of its failure to allow for accelerated depreciation allowances.

Similarly, firms with a greater variance in earnings (Types A and B) tend to have lower effective tax rates, which presumably is a reflection of their greater ability to shield current profits with losses from previous periods. The current debt-total assets ratio is associated with significantly lower effective tax rates. This is an interesting result, because at first glance it appears to contradict the hypothesis that higher taxes should be associated with more debt financing. Debt-total asset ratios, however, are the cumulative result of a large number of financing decisions and, hence, the coefficient should be interpreted as reflecting the greater amount of interest tax shields of highly leveraged firms. The estimated coefficient on Altman's (1968) bankruptcy predictor is negative, as expected, but the coefficients are small and not significant.

Poterba (1992) shows that effective corporate tax rates reached their peak in 1980 with 42.6 percent (the statutory tax rate in 1980 was 46 percent) and declined in the following years with the exception of 1987 when effective tax rates increased from 30 percent in 1986 to 37 percent in 1987 (in 1988 the effective tax rate decreased back to 30 percent). This pattern is roughly reflected in the negative coefficients for most periods after 1980 (the omitted category). All other coefficients are insignificant although most have the predicted sign. 
Table 1. Estimation of Effective Tax Rates

\begin{tabular}{|c|c|c|c|}
\hline Variable & $\begin{array}{c}\text { Model II: One- } \\
\text { Period Ahead } \\
\text { Tax Rates }\end{array}$ & $\begin{array}{l}\text { Model III: } \\
\text { Unweighted } \\
\text { Five-Period } \\
\text { Ahead Taxes } \\
\end{array}$ & $\begin{array}{c}\text { Model IV: } \\
\text { Weighted Five- } \\
\text { Period Ahead } \\
\text { Taxes }\end{array}$ \\
\hline "Good" effective tax rate & $\begin{array}{l}0.679 * * \\
(0.034)\end{array}$ & $\begin{array}{l}0.48^{* *} \\
(0.022)\end{array}$ & $\begin{array}{l}0.603^{* *} \\
(0.023)\end{array}$ \\
\hline "Bad" effective tax rate & $\begin{array}{l}0.044^{* *} \\
(0.005)\end{array}$ & $\begin{array}{c}0.003 \\
(0.0027)\end{array}$ & $\begin{array}{c}0.003 \\
(0.0028)\end{array}$ \\
\hline Tax loss carryforwards & $\begin{array}{c}0.009 \\
(0.006)\end{array}$ & $\begin{array}{c}0.005 \\
(0.0038)\end{array}$ & $\begin{array}{c}0.006 \\
(0.004)\end{array}$ \\
\hline Investment tax credits & $\begin{array}{c}-3.425 * * \\
(1.436)\end{array}$ & $\begin{array}{l}-4.178^{* *} \\
(0.87)\end{array}$ & $\begin{array}{c}-3.672^{* *} \\
(0.883)\end{array}$ \\
\hline Depreciation & $\begin{array}{c}-0.202^{* *} \\
(0.067)\end{array}$ & $\begin{array}{c}-0.151^{* *} \\
(0.044)\end{array}$ & $\begin{array}{c}-0.190 * * \\
(0.045)\end{array}$ \\
\hline $\begin{array}{l}\text { Investment tax credits * } \\
\text { bankruptcy predictor }\end{array}$ & $\begin{array}{c}1.043 \\
(1.316)\end{array}$ & $\begin{array}{l}1.409^{*} \\
(0.839)\end{array}$ & $\begin{array}{c}1.112 \\
(0.851)\end{array}$ \\
\hline Bankruptcy predictor & $\begin{array}{l}-0.0002 \\
(0.0024)\end{array}$ & $\begin{array}{l}-0.0003 \\
(0.0021)\end{array}$ & $\begin{array}{c}-0.0004 \\
(-0.0022)\end{array}$ \\
\hline Current debt/total asset ratio & $\begin{array}{l}-0.082^{* *} \\
(0.031)\end{array}$ & $\begin{array}{c}-0.095^{* *} \\
(0.022)\end{array}$ & $\begin{array}{c}-0.049 * * \\
(0.022)\end{array}$ \\
\hline Variance of earnings, Type A & $\begin{array}{c}-0.270^{* *} \\
(0.068)\end{array}$ & $\begin{array}{c}-0.286^{* *} \\
(0.046)\end{array}$ & $\begin{array}{c}-0.266^{* *} \\
(0.046)\end{array}$ \\
\hline Variance of earnings, Type B & $\begin{array}{l}-0.142 \\
(0.124)\end{array}$ & $\begin{array}{c}-0.373 \\
(0.711)\end{array}$ & $\begin{array}{c}-0.504 \\
(0.722)\end{array}$ \\
\hline Variance A *bankruptcy predictor & $\begin{array}{c}0.003 \\
(0.013)\end{array}$ & $\begin{array}{c}0.002 \\
(0.015)\end{array}$ & $\begin{array}{c}0.002 \\
(0.015)\end{array}$ \\
\hline 1979 & 0.006 & -0.003 & -0.002 \\
\hline 1981 & $-0.036^{*}$ & 0 & 0 \\
\hline 1982 & 0.018 & $0.024^{*}$ & $0.026 * *$ \\
\hline 1983 & 0.03 & 0.008 & 0.018 \\
\hline 1984 & 0 & 0 & 0 \\
\hline 1985 & 0 & 0 & 0 \\
\hline 1986 & 0.026 & 0 & 0 \\
\hline
\end{tabular}


Table 1 (concluded). Estimation of Effective Tax Rates

\begin{tabular}{l|ccc}
\hline \multicolumn{1}{l}{ Variable } & $\begin{array}{c}\text { Model II: One- } \\
\text { Period Ahead } \\
\text { Tax Rates }\end{array}$ & $\begin{array}{c}\text { Model III: } \\
\text { Unweighted } \\
\text { Five-Period } \\
\text { Ahead Taxes }\end{array}$ & $\begin{array}{c}\text { Model IV: } \\
\text { Weighted Five- } \\
\text { Period Ahead } \\
\text { Taxes }\end{array}$ \\
\hline 1987 & $-0.039^{*}$ & 0 & 0 \\
1988 & $-0.043^{* *}$ & & \\
1989 & -0.029 & & \\
1990 & -0.015 & & \\
1991 & -0.015 & & $0.113^{* *}$ \\
Constant & $0.115^{* *}$ & $0.157^{* *}$ & 8,361 \\
\hline $\mathrm{n}$ & 12,077 & 8,361 & 0.13 \\
\hline $\mathrm{R}^{2}$ & 0.12 & 0.13 & \\
\hline
\end{tabular}

** significant at the 5 percent level.

* significant at the 10 percent level.

Note: Definitions and descriptive statistics are in Appendices I and II, respectively. Recall that Model I uses actual one-period ahead effective tax rates. Model II is a random effects model, estimated by feasible generalized least squares; Models III and IV are estimated by two-factor fixed effects. Standard errors are in parentheses.

\section{ESTIMATION OF FINANCING DECISIONS}

As a second step the measures of the firms' expectation of future effective tax rates obtained in the previous section are related to a continuous measure of the firms' financing decision. MacKie-Mason (1990a) first pointed out that it is important to use measures of incremental financing decisions rather than debt-equity ratios, because the debt-equity ratio of the firm is the sum of many financing decisions and changing expectations about future tax rates. A simple measure of the incremental financing decision of firms is the change in total debt scaled by the firms' total assets. This dependent variable permits one to calculate elasticities of debt financing with respect to effective corporate tax rates and obtain a more accurate picture of the magnitude of tax effects on firms' financing decisions. ${ }^{18}$

${ }^{18}$ This continuous approach also does not select firms based on their financing choice. More importantly, information about the magnitude of debt or equity issues is utilized, unlike in the discrete choice approach used by MacKie-Mason (1990a). 
If firms with higher expected tax rates have lower total assets, we might mistakenly interpret an estimated positive coefficient as evidence in favor of the tax hypothesis. Therefore, the level of total assets is included separately as an explanatory variable. Similarly, if firms with higher effective tax rates have more profitable investment opportunities, the tax coefficient would be biased upward. A measure of the firms' current investment is included to control for this effect.

The estimating equation for firms' financing decision is of the form

$$
D_{t+1 i}=\beta_{0}+\beta_{i}+\beta_{t}+\beta_{1} \hat{E}_{t i}\left[P V_{t a x, i}\right]+\beta_{2} A_{t i}+\epsilon_{t i}
$$

with the restriction

$$
\sum_{i=1}^{N} \beta_{i}=\sum_{t=1}^{T} \beta_{t}=0
$$

and where $D_{t+1 i}$ represents the change in total debt divided by the level of total assets for firm $i$ in period $\mathrm{t}+1$, and $\hat{E}_{t i}\left[P V_{\text {tax }, i}\right]$ denotes the respective proxy used for the expected discounted tax rates associated with the investment of firm $i$. To account for the effect of very high or low effective tax rates (see also Section III.B), we split $\hat{E}_{t i}\left[P V_{i, t a x}\right]$ into two variables: a "good" tax rate which is equal to the predicted value of Models II to IV estimated previously if the predicted value is between 0 and 1 and 0 otherwise, and a "bad" tax rate which is equal to the predicted value if the predicted value is outside the range of 0 and 1 and 0 otherwise. $\mathrm{A}_{\mathrm{ti}}$ represents the vector of variables measuring alternative theories of capital structure choice. These variables and the underlying theories are discussed below. We estimate a two-factor fixed effects model allowing for effects across time and firms.

\section{OTHER THEORIES OF CAPITAL STRUCTURE CHOICE}

Most alternative theories of capital structure choice are based on the idea that managers, stockholders, and bondholders of the firm have diverging interests, incomplete information, and are unable to completely monitor each other. Unfortunately, there is currently no theory that unifies the tax approach to capital structure choice with approaches based on asymmetric information. This paper is primarily concerned with tax effects, but the failure to control for these alternative theories may bias the estimates. Hence, proxies for several alternative theories that others have found to be significantly related to firms' financing decisions are introduced into the empirical specification. ${ }^{19}$ Because we are following MacKie-Mason (1990a) very closely in the choice and definition of these proxies, only a very brief description of the variables and their predicted effect on the incremental debt-equity decision is needed.

${ }^{19}$ For a survey, see Titman and Wessels (1988). 
Myers and Majluf (1984) and Myers (1984) propose a model that is concerned with the decision between external (bond issues, stock issues) versus internal financing (bank loans, retained earnings), and not with the choice between debt and equity. The relative infrequency of stock and bond issues is explained with a simple "lemons" model. If managers have information about the firm that investors do not, firms will only be able to issue stock at a discount. Hence, firms will issue stock only as a last resort after having explored all other possible sources of funds. In the remainder of the paper this theory is referred to as the "signalling hypothesis."

Since Myers (1984) and Myers and Majluf's (1984) theory is concerned with the choice between external and internal financing, retained earnings scaled by total assets are included as an explanatory variable. Asymmetric information increases the cost of public issues of either debt or equity. The inclusion of retained earnings as an explanatory variable controls for internal equity financing. Conditioning on retained earnings the equity alternative (stock issues) should be more affected by the "lemons" problem than the debt alternative (bank loans and bond issues) measured by the dependent variable. If internal and external equity financing are imperfect substitutes, firms with more retained earnings will use less debt financing.

According to the traditional view on dividend taxation, dividends are costly signals to the current shareholders. ${ }^{20}$ If a firm pays dividends, new shareholders might view a dividend paying firm more favorably than a nondividend paying firm. Controlling for retained earnings, a dividend paying firm should use less debt finance, because it is able to issue equity more cheaply (the variable is coded as 1 if firms pay dividends). Along similar lines, investors will require a smaller lemons premium if the stock price recently increased, which also might signal a well performing firm (MacKie-Mason, 1990). Hence, we use the previous year's change in the firms' stock price as an explanatory variable.

Myers (1977) presents a model in which a large amount of outstanding debt causes underinvestment in new projects, because managers require the investment to generate a sufficiently large return to not only satisfy the debt payments (including principal) but also generate an incremental return for the stockholders. The first best condition would only require that the investment generates an acceptable return on the incremental investment, and, hence, there is underinvestment. Jensen and Meckling (1976) argue in a related model that firms with large debt burdens may take excessive risks because the stockholders gain if the risk succeeds, but only the bondholders lose if it fails. Hence, it should be very costly for these firms to issue any new debt.

Proxies related to this set of agency theories measure moral hazard and hence are related to the amount of debt already issued (MacKie-Mason, 1990a, 1990b). The ratio of plant and equipment to total assets indicates the relative importance of the assets already committed.

\footnotetext{
${ }^{20}$ For a comprehensive summary of the "new" versus the "old" views on dividend taxation, see Zodrow (1989).
} 
Agency theory predicts that it should be cheaper to raise additional debt for firms with more assets committed. In addition, the firms' research and development expenditures as well as its advertising expenditures, whose values depend on future investment decisions (see Bradley, Jarrell, and Kim (1984), and MacKie-Mason (1990a)), are used to measure the amount of intangible assets in the firm. If there are more intangible assets in the firm, there might be a greater potential for moral hazard and, hence, agency theory predicts that firms with larger R\&D expenditures or larger advertising expenditures use less debt financing.

Jensen (1986) considers the opposite case in which firms with large amounts of free cash flow and few profitable investment opportunities might invest in projects with submarket returns, because that will keep the control of the funds with the managers. Stockholders, in an attempt to increase the amounts of funds that flow out of the firm might want to swap stocks for bonds. We follow MacKie-Mason (1990a) in the choice of proxies for these theories related to investment inefficiencies. According to Jensen (1986) firms with a lot of free cash flow and few profitable investment opportunities have an incentive to choose debt. We include Auerbach's (1985) measure of cash deficit after average dividends and investment expenditures as a measure of "free cash flow." In addition we attempt to account for differences in profitable investment opportunities by using the ratio of the market value of equity and the book value of equity as an explanatory variable. If a firm has a large number of profitable investment opportunities that should be reflected in a high market value of equity relative to the book value. All three hypotheses are lumped together and labeled "agency theory" in the remainder of the paper.

Firms might use less debt because of the direct and indirect costs associated with bankruptcy. Again following MacKie-Mason (1990a) two measures of the variability of firms' earnings, as well as Altman's (1968) bankruptcy indicator, are included as independent variables into the specification.

Definitions of all variables are reported in Appendix I, summary statistics are in Appendix II.

\section{ESTIMATION RESULTS FOR FIRMS' FINANCING DECISIONS}

Table 2 reports results from two-factor fixed effects models using the predicted values of Models II to IV as proxies for firms' expectations. Recall that Model I uses the actual oneperiod ahead effective tax rate. The dependent variable is the change in debt divided by the firms' total assets. All four proxies for expected effective tax rates are positively related to firms' incremental financing decisions. The estimated coefficients are significant at any conventional significance level in all four models. Firms with higher expected effective tax rates use more debt financing. Firms issue debt on average at a rate of about 1.8 percent of their total assets in every period. If all firms paid the statutory income tax rate on all profits this ratio would increase to 3.1 percent. In contrast, if there were no corporate income tax the ratio would decrease to -.3 percent, i.e., firms would issue equity to repurchase debt. 
Table 2. Expected Tax Rates and Financing Decisions

\begin{tabular}{|c|c|c|c|c|c|}
\hline & Variable & Model I & Model II & Model III & Model IV \\
\hline \multirow{2}{*}{$\begin{array}{l}\text { Tax } \\
\text { hypothesis }\end{array}$} & "Good" effective tax rates & $\begin{array}{l}0.087^{* *} \\
(0.012)\end{array}$ & $\begin{array}{l}0.11 * * \\
(0.015)\end{array}$ & $\begin{array}{c}0.159 * * \\
(0.019)\end{array}$ & $\begin{array}{l}0.13 * * \\
(0.016)\end{array}$ \\
\hline & "Bad" effective tax rates & $\begin{array}{c}0.002 \\
(0.002) \\
\end{array}$ & $\begin{array}{c}0.032 \\
(0.038) \\
\end{array}$ & $\begin{array}{c}0.412^{* *} \\
(0.152) \\
\end{array}$ & $\begin{array}{l}0.468^{* *} \\
(0.146) \\
\end{array}$ \\
\hline \multirow[t]{4}{*}{$\begin{array}{l}\text { Bankruptcy } \\
\text { costs }\end{array}$} & Variance of earnings, Type A & $\begin{array}{l}-0.114^{* *} \\
(0.027)\end{array}$ & $\begin{array}{l}-0.099 * * \\
(0.026)\end{array}$ & $\begin{array}{c}-0.052 * * \\
(0.025)\end{array}$ & $\begin{array}{l}-0.058 * * \\
(0.025)\end{array}$ \\
\hline & Variance of earnings, Type B & $\begin{array}{c}0.391 \\
(0.442)\end{array}$ & $\begin{array}{c}0.452 \\
(0.444)\end{array}$ & $\begin{array}{l}0.611^{*} \\
(0.347)\end{array}$ & $\begin{array}{c}0.697 \\
(0.350)\end{array}$ \\
\hline & Variance $A *$ bankruptcy predictor & $\begin{array}{l}-0.004 \\
(0.004)\end{array}$ & $\begin{array}{l}-0.005 \\
(0.004)\end{array}$ & $\begin{array}{c}-0.021 * * \\
(0.007)\end{array}$ & $\begin{array}{r}-0.021 * * \\
(0.007)\end{array}$ \\
\hline & Bankruptcy predictor & $\begin{array}{c}0.0005 \\
(0.0008) \\
\end{array}$ & $\begin{array}{r}0.0007 \\
(0.0008) \\
\end{array}$ & $\begin{array}{c}0.003^{* *} \\
(0.001) \\
\end{array}$ & $\begin{array}{l}0.003^{* *} \\
(0.001) \\
\end{array}$ \\
\hline \multirow[t]{5}{*}{ Agency costs } & $\begin{array}{l}\text { Fraction of assets in plant and } \\
\text { equipment }\end{array}$ & $\begin{array}{c}0.004 \\
(0.004)\end{array}$ & $\begin{array}{l}0.007 * \\
(0.003)\end{array}$ & $\begin{array}{l}0.0005 \\
(0.003)\end{array}$ & $\begin{array}{l}0.0003 \\
(0.003)\end{array}$ \\
\hline & R\&D expenditures & $\begin{array}{l}0.122^{* *} \\
(0.056)\end{array}$ & $\begin{array}{l}0.139^{* *} \\
(0.049)\end{array}$ & $\begin{array}{c}0.073 \\
(0.045)\end{array}$ & $\begin{array}{l}0.078^{*} \\
(0.045)\end{array}$ \\
\hline & Advertising expenditures & $\begin{array}{c}0.065 \\
(0.063)\end{array}$ & $\begin{array}{c}0.053 \\
(0.057)\end{array}$ & $\begin{array}{c}0.005 \\
(0.053)\end{array}$ & $\begin{array}{c}0.008 \\
(0.053)\end{array}$ \\
\hline & Free cash flow & $\begin{array}{l}0.0007 \\
(0.004)\end{array}$ & $\begin{array}{l}-0.0004 \\
(0.004)\end{array}$ & $\begin{array}{l}0.007^{*} \\
(0.004)\end{array}$ & $\begin{array}{l}0.007^{*} \\
(0.004)\end{array}$ \\
\hline & Market value of equity/book value & $\begin{array}{r}-0.256 \\
(0.185) \\
\end{array}$ & $\begin{array}{l}-0.241 \\
(0.185) \\
\end{array}$ & $\begin{array}{c}-1.076^{* *} \\
(0.367) \\
\end{array}$ & $\begin{array}{r}-1.084 * * \\
(0.367) \\
\end{array}$ \\
\hline \multirow[t]{2}{*}{ Signalling } & Change in stock price & $\begin{array}{c}0.183 \\
(0.127)\end{array}$ & $\begin{array}{c}0.199 \\
(0.127)\end{array}$ & $\begin{array}{c}0.187 \\
(0.119)\end{array}$ & $\begin{array}{c}0.188 \\
(0.119)\end{array}$ \\
\hline & Dividend paying firm & $\begin{array}{l}0.014^{* *} \\
(0.005) \\
\end{array}$ & $\begin{array}{l}0.014^{* *} \\
(0.005) \\
\end{array}$ & $\begin{array}{c}0.003 \\
(0.005) \\
\end{array}$ & $\begin{array}{c}0.002 \\
(0.005) \\
\end{array}$ \\
\hline \multirow[t]{3}{*}{ Other } & Investment & $\begin{array}{c}0.082 * * \\
(0.009)\end{array}$ & $\begin{array}{l}0.09 * * \\
(0.009)\end{array}$ & $\begin{array}{c}0.073^{* *} * \\
(0.008)\end{array}$ & $\begin{array}{c}0.071^{* *} \\
(0.008)\end{array}$ \\
\hline & Net assets & $\begin{array}{l}-0.224^{*} \\
(0.125)\end{array}$ & $\begin{array}{l}-0.175 \\
(0.123)\end{array}$ & $\begin{array}{c}-0.371^{*} \\
(0.2)\end{array}$ & $\begin{array}{c}-0.399 * * \\
(0.2)\end{array}$ \\
\hline & Retained earnings & $\begin{array}{c}0.012^{* *} \\
(0.004) \\
\end{array}$ & $\begin{array}{c}0.01 * * \\
(0.004) \\
\end{array}$ & $\begin{array}{c}-0.003 \\
(0.003) \\
\end{array}$ & $\begin{array}{c}-0.002 \\
(0.003) \\
\end{array}$ \\
\hline
\end{tabular}


Table 2 (concluded). Expected Tax Rates and Financing Decisions

\begin{tabular}{l|l|ccccc}
\hline \multicolumn{2}{|c}{ Variable } & Model I & Model II & Model III & Model IV \\
\hline \multirow{2}{*}{ Total assets } & $\begin{array}{c}-0.144 \\
(0.093)\end{array}$ & $\begin{array}{c}0.12 \\
(0.092)\end{array}$ & $\begin{array}{c}-0.223 \\
(0.155)\end{array}$ & $\begin{array}{c}-0.245 \\
(0.155)\end{array}$ \\
\hline & & 12,077 & 12,077 & 8,361 & 8,361 \\
\hline
\end{tabular}

**significant at the 5 percent level.

*significant at the 10 percent level.

Note: Definitions and summary statistics are in Appendices I and II, respectively. The dependent variable is the change in debt divided by total assets. Two-factor fixed effects model. Fixed effects for firms and periods not reported. Standard errors are in parentheses.

Results for specifications in which the expected tax rate is not split are reported in Appendix IV. Not splitting the variable leads to substantial understatement of tax effects for Models I and II and to a slight overstatement for Models III and IV.

The results presented in Table 2 provide some support for agency theory as an explanation for financing decisions of firms, especially in Models III and IV. Firms with more free cash flow as measured by Auerbach's (1985) cash deficit variable, tend to use more debt, albeit the effect is only statistically significant at the 5 percent level in Models III and IV. This evidence is consistent with the idea that stockholders attempt to discipline managers through the interest obligations. Research and development expenditures are positively correlated (and significant in three of the four models) with firms' incremental debt financing, which is inconsistent with agency theory. The estimated coefficient for advertising expenditures is not significantly different from zero in any specification. It appears, however, that firms with more growth opportunities and, therefore, higher ratios of the market value of equity to the book value of equity, use significantly (at the 5 percent level in two specifications) less debt finance, which is consistent with the predictions of the agency theory. The estimated coefficients are the same sign as MacKie-Mason's with the exception of research and development expenditures, for which MacKie-Mason obtained a negative coefficient.

There is no evidence supporting the signalling hypothesis. The estimated coefficients on dividend paying firms and on the change in stock price are all positive and two are significant at the 5 percent level. The result contradicts the notion that dividends or increases in stock prices are perceived as favorable signals by investors and, hence, decrease the cost of stock issues. MacKie-Mason also finds a positive coefficient on dividends, but obtains the expected negative coefficient on the change in the stock price. These findings support results obtained by Loderer and Mauer (1992), who test whether equity issuing firms are more likely to pay or increase dividends than nonissuing firms. If dividends were an important signal to shareholders, firms who plan to issue stock should be more likely to start paying dividends or 
increase dividend payouts preceding the issue. The evidence presented in Loderer and Mauer contradicts that idea.

The evidence on the bankruptcy hypothesis is somewhat supportive. The variance of earnings, Type A, has the expected negative sign and is statistically significant. In addition, when it is interacted with Altman's (1968) bankruptcy predictor it remains negative and significant in two specifications. The variance of earnings, Type B, is positive and insignificant in all but one specification.

The significantly positive coefficient on the investment variable confirms the earlier suspicion that firms with larger investment projects issue more debt. There does not appear to be a significant relationship between the level of total assets and financing; the coefficients on the total asset variable are insignificant.

In summary, important and statistically significant tax effects have been found using four different proxies for expected effective tax rates. Some support for the agency theory of capital structure choice and for bankruptcy costs is also found. The evidence provides no support for the signalling hypothesis.

Recall that to generate a balanced panel we dropped all firms with incomplete sets of data. This leads to the exclusion of 4,853 observations or approximately 400 firms. Column 1 of Table 3 reports probit results for the probability of remaining in the balanced sample. The dependent variable is equal to one if the firm is in the balanced panel. Firms with complete sets of data face significantly higher effective tax rates, their earnings are less variable, they are less likely to declare bankruptcy, have significantly less free cash flow, have higher market values relative to their book values, and are much more likely to pay dividends. In addition, firms in the balanced sample invest more, have more retained earnings, and are larger.

Given the significant differences between the two groups we present results using Model I (actual one-period ahead tax rates as the measure of firms' expected tax rate) for the unbalanced panel in column 2 of Table 3 . These results cannot be directly compared to Table 2, because they are obtained using ordinary least squares regression (with time and industry dummies) and, therefore, do not allow for fixed effects across firms. Nevertheless, the similarity of most estimated coefficients across Tables 2 and 3 can be taken as suggestive evidence that the results in Table 2 are not driven by sample selection bias. 
Table 3. Probit and Unbalanced Panel Results

\begin{tabular}{|c|c|c|c|}
\hline & Variable & Probit & $\begin{array}{c}\text { Unbalanced } \\
\text { Panel }\end{array}$ \\
\hline \multirow[t]{2}{*}{$\begin{array}{l}\text { Tax } \\
\text { hypothesis }\end{array}$} & "Good" effective tax rates & $\begin{array}{c}0.358^{* *} \\
(0.076)\end{array}$ & $\begin{array}{l}0.193^{* *} \\
(0.02)\end{array}$ \\
\hline & "Bad" effective tax rates & $\begin{array}{l}-0.016 \\
(0.011) \\
\end{array}$ & $\begin{array}{r}0.084 \\
(0.069) \\
\end{array}$ \\
\hline \multirow[t]{4}{*}{$\begin{array}{l}\text { Bankruptcy } \\
\text { costs }\end{array}$} & Variance of earnings, Type A & $\begin{array}{l}-1.372^{* *} \\
(0.151)\end{array}$ & $\begin{array}{c}-0.073^{* *} \\
(0.019)\end{array}$ \\
\hline & Variance of earnings, Type B & $\begin{array}{c}0.417 \\
(0.389)\end{array}$ & $\begin{array}{c}0.09 \\
(0.169)\end{array}$ \\
\hline & $\begin{array}{l}\text { Variance } A * \text { bankruptcy } \\
\text { predictor }\end{array}$ & $\begin{array}{l}0.061 * * \\
(0.027)\end{array}$ & $\begin{array}{l}-0.009 * * \\
(0.003)\end{array}$ \\
\hline & Bankruptcy predictor & $\begin{array}{l}-0.009 * * \\
(0.004) \\
\end{array}$ & $\begin{array}{l}0.0013 * * \\
(0.0005) \\
\end{array}$ \\
\hline \multirow[t]{5}{*}{ Agency costs } & $\begin{array}{l}\text { Fraction of assets in plant and } \\
\text { equipment }\end{array}$ & $\begin{array}{l}-0.01 \\
(0.01)\end{array}$ & $\begin{array}{l}-0.002 \\
(0.001)\end{array}$ \\
\hline & $R \& D$ expenditures & $\begin{array}{c}-0.253^{*} \\
(0.147)\end{array}$ & $\begin{array}{c}0.007 \\
(0.005)\end{array}$ \\
\hline & Advertising expenditures & $\begin{array}{c}0.938 \\
(0.331)\end{array}$ & $\begin{array}{l}0.183 * * \\
(0.042)\end{array}$ \\
\hline & Free cash flow & $\begin{array}{l}-0.063^{* *} \\
(0.022)\end{array}$ & $\begin{array}{l}-0.003 \\
(0.002)\end{array}$ \\
\hline & $\begin{array}{l}\text { Market value of equity/book } \\
\text { value }\end{array}$ & $\begin{array}{c}0.494^{* *} \\
(0.036) \\
\end{array}$ & $\begin{array}{c}0.994^{* *} \\
(0.316) \\
\end{array}$ \\
\hline \multirow[t]{2}{*}{ Signalling } & Change in stock price & $\begin{array}{c}-0.094 \\
(0.657)\end{array}$ & $\begin{array}{c}0.973 \\
(0.881)\end{array}$ \\
\hline & Dividend paying firm & $\begin{array}{c}0.729 * * \\
(0.026) \\
\end{array}$ & $\begin{array}{l}0.016 * * \\
(0.004) \\
\end{array}$ \\
\hline \multirow[t]{3}{*}{ Other } & Investment & $\begin{array}{c}0.074^{* *} \\
(0.025)\end{array}$ & $\begin{array}{c}0.016^{* *} \\
(0.004)\end{array}$ \\
\hline & Net assets & $\begin{array}{c}-0.394^{* *} \\
(0.163)\end{array}$ & $\begin{array}{c}-0.004 \\
(0.141)\end{array}$ \\
\hline & Retained earnings & $\begin{array}{l}0.206 * * \\
(0.022) \\
\end{array}$ & $\begin{array}{l}-0.337 \\
(0.791) \\
\end{array}$ \\
\hline
\end{tabular}


Table 3 (concluded). Probit and Unbalanced Panel Results

\begin{tabular}{l|l|cc}
\hline \multicolumn{2}{c}{ Variable } & Probit & $\begin{array}{c}\text { Unbalanced } \\
\text { Panel }\end{array}$ \\
\hline & Total assets & $\begin{array}{c}0.377^{* *} \\
(0.129)\end{array}$ & $\begin{array}{c}-0.029 \\
(0.107)\end{array}$ \\
\hline & $\mathrm{n}$ & 16,930 & 16,930 \\
\hline
\end{tabular}

**significant at the 5 percent level.

*significant at the 10 percent level.

Note: Definitions and summary statistics are in Appendices I and II, respectively. The dependent variable for the probit model is whether the firm is included in the balanced panel ( 1 if included). For the unbalanced panel the model is estimated by ordinary least squares with time and industry dummy variables. Standard errors are in parentheses.

\section{viI. Conclusion}

This paper uses a simple rational expectations approach to estimate firms' expectations of future effective tax rates. Using a large Compustat panel data set of U.S. firms, we find that current average effective tax rates have substantial predictive power for the estimation of expected corporate tax rates. Moreover, controlling for current effective tax rates, investment tax credits and depreciation are powerful predictors of lower future effective tax rates.

In the second stage the estimated expected tax rates are related to U.S. firms' incremental financing decision, controlling for other theories of capital structure choice. The results obtained support the notion that firms take expected effective tax rates into consideration when choosing between debt and equity to finance their investment projects and corroborate earlier findings in MacKie-Mason (1990a). In contrast to MacKie-Mason, however, we have been able to estimate tax effects for firms that represent most of the corporate market value at the New York and American stock exchanges. It was also possible to make fairly accurate statements about the magnitude of the effects and find that they are quite substantial. An increase in expected effective tax rates (due to increases in statutory rates, changes in depreciation allowances or the reintroduction of the investment tax credit) would, given the results obtained in this paper, have a large effect on the commercial debt and equity markets in the United States. For example, if all firms paid the current statutory corporate tax rate (that would represent a tax increase of between 10 to 15 percentage points) the value of annual debt issues would increase by 72 percent (or 1.4 percentage points; from 1.8 percent to 3.1 percent). 
There is some evidence that agency and bankruptcy costs have an important influence on the debt equity choice of managers, but no evidence to support Myers (1984) signalling hypothesis. All of these findings are consistent with the previous literature.

It is very difficult to unambiguously reject or support any of the alternative theories of the financing decision of firms, because the choice of proxies is always somewhat arbitrary. It appears useful to attempt to unify these theories with the tax hypothesis, in part because it is likely that there are important interactions between the signalling, agency, and tax hypotheses. To develop an integrating theory of capital structure choice remains an important avenue for future research.

Corporate tax revenues have declined steadily since World War II in the United States. It would be incorrect, however, to conclude that therefore corporate taxes have little importance for corporate decisions. This paper, and Gropp (1995) for German firms, have presented evidence that the distortionary effect of corporate taxation on firms' financing is very likely substantial both in Germany and in the United States. 


\section{APPENDIX I. DEFinitions}

Tax loss carryforward $=$ (book tax loss carryforward)/sales;

Investment tax credit $=$ investment tax credits/sales;

Depreciation $=$ depreciation $/$ sales;

EBIT $=$ Earnings before interest payments and taxes;

Bankruptcy predictor is Altman's (1968) bankruptcy predictor excluding the ratio of market equity to book debt;

Bankruptcy predictor $=3.3 \mathrm{EBIT} /($ total assets $)+1.0 \mathrm{sales} /($ total assets $)+1.4$ (retained earnings)/(total assets) +1.2 (working capital)/(total assets);

$R$ \& $D$ expenditures $=$ research and development expenditures/sales (if $R \& D$ is missing, the variable is coded as zero);

Advertising expenditures $=($ advertising expenditures $) /$ sales (if advertising expenditures are missing, the variable is coded as zero);

EBIDT = earnings before interest, depreciation and taxes;

Variance of earnings, Type $A=$ standard deviation of $\left(E\right.$ BIDT $\left.t-E_{t}-B_{t-1}\right)$ divided by mean of total assets for the sample period;

Variance of earnings, Type $\mathrm{B}=$ standard deviation of $\left(\mathrm{EBIDT}_{\mathbf{t}}-\mathrm{EBIDT}_{\mathrm{t}-1}\right) / \mathrm{EBIDT}_{\mathrm{t}-1}$;

Fraction of assets in plant and equipment $=$ (plant-accumulated depreciation) $) /($ total assetscurrent liabilities);

Free cash flow $=$ (capital expenditures + average dividends-(cash flow + capital expenditures*[(total debt)/(net assets)]))/(net sales), where average dividends are the mean dividends during the sample period;

Market value of equity/book value of equity $=(($ end of year stock price)*(number of shares outstanding))/(book value of common and preferred stock);

Current debt-total assets ratio $=($ long-term debt $) /($ total assets $) ;$

Dividend paying firm $=1$ if firm pays dividends either on common or preferred stock; 0 otherwise; 
Change in stock price $=$ (stock price beginning of current year)-(stock price beginning of previous year);

Investment $=(($ change in fixed assets $)+$ depreciation $) /($ total assets $) ;$

Net assets $=$ total assets-current payables;

EBTDO = earnings before taxes and discontinued operations;

Current effective tax rates $=$ (income taxes paid)/EBITDO if EBITDO $>0$;

Current effective tax rates $=$ statutory corporate tax rate if EBITDO $<0 \&$ (income taxes paid) $>0$;

Current effective tax rates $=-$ (statutory corporate tax rate) if EBITDO $<0$ \& (income taxes paid) $<0$;

Change in debt divided by total assets $=\left(\right.$ total debt $_{t+1}-$ total debt $\left._{\mathrm{t}}\right) /\left(\right.$ total assets $\left._{\mathrm{V}}\right) ;$

Investment $=$ investment $/$ total assets;

Retained earnings $=$ retained earnings/total assets . 
APPENDIX II. SUMMARY STATISTICS

\begin{tabular}{|c|c|c|c|c|c|}
\hline Variable & $\underline{\mathbf{n}}$ & Mean & Std. Dev. & Minimum & Maximum \\
\hline Change in debt/total assets & 12,077 & 0.018 & 0.172 & -9.765 & 1.285 \\
\hline Effective corporate tax rates & 12,077 & 0.233 & 0.979 & -39.485 & 66.069 \\
\hline "Good" tax rate & 12,077 & 0.256 & 0.145 & 0.000 & 0.982 \\
\hline "Bad" tax rate & 12,077 & -0.023 & 0.963 & -39.485 & 66.069 \\
\hline Tax loss carryforwards & 12,077 & 0.052 & 0.714 & -0.784 & 68.299 \\
\hline Investment tax credits & 12,077 & 0.002 & 0.005 & -0.007 & 0.208 \\
\hline Depreciation & 12,077 & 0.052 & 0.068 & 0.000 & 4.336 \\
\hline Bankruptcy predictor & 12,077 & 0.614 & 4.319 & -210.075 & 252.749 \\
\hline $\begin{array}{l}\text { Research and development } \\
\text { expenditures }\end{array}$ & 12,077 & 0.016 & 0.033 & 0.000 & 0.799 \\
\hline Advertising expenditures & 12,077 & 0.011 & 0.028 & 0.000 & 0.582 \\
\hline Variance of earnings, Type A & 12,077 & 0.06 & 0.066 & 0.001 & 1.519 \\
\hline Variance of earnings, Type B & 12,077 & 434.8 & $34,939.8$ & 0.014 & $3,796,310$ \\
\hline $\begin{array}{l}\text { Variance of earnings * } \\
\text { bankruptcy predictor }\end{array}$ & 12,077 & 0.042 & 0.823 & -34.540 & 64.096 \\
\hline $\begin{array}{l}\text { Investment tax credits * } \\
\text { bankruptcy predictor }\end{array}$ & 12,077 & 0.001 & 0.005 & -0.266 & 0.225 \\
\hline $\begin{array}{l}\text { Fraction of assets in plant and } \\
\text { equipment }\end{array}$ & 12,077 & 0.565 & 0.488 & -27.648 & 18.839 \\
\hline Free cash flow & 12,077 & -0.097 & 0.414 & -35.925 & 18.736 \\
\hline $\begin{array}{l}\text { Market value of equity/book } \\
\text { value of equity }\end{array}$ & 12,077 & 1.797 & 8.357 & 0.000 & 688.882 \\
\hline Current debt/total asset ratio. & 12,077 & 0.215 & 0.155 & 0.000 & 3.323 \\
\hline Change in stock price & 12,077 & 0.552 & 12.548 & -329 & 201.875 \\
\hline Net assets & 12,077 & 2060 & $6,149.070$ & $-1,393$ & 157,719 \\
\hline Dividend paying firm & 12,077 & 0.851 & 0.356 & 0.000 & 1.000 \\
\hline Retained earnings & 12,077 & 0.265 & 0.434 & -22.618 & 1.122 \\
\hline Investment & 12,077 & 0.098 & 0.178 & -5.933 & 4.501 \\
\hline
\end{tabular}

Note: Definitions of all variables are in Appendix I. 
APPENDIX III. ADDITIONAL RESULTS FOR THE ESTIMATION OF EXPECTED TAX RATES

\begin{tabular}{|c|c|c|c|}
\hline Variable & $\begin{array}{l}\text { Model II: One-Period } \\
\text { Ahead Tax Rates }\end{array}$ & $\begin{array}{l}\text { Model III: Unweighted } \\
\text { Five-Period Ahead Taxes }\end{array}$ & $\begin{array}{c}\text { Model IV: Weighted } \\
\text { Five-Period Ahead } \\
\text { Taxes }\end{array}$ \\
\hline Current effective tax rates & $\begin{array}{l}0.0434 * * \\
(0.0044)\end{array}$ & $\begin{array}{l}0.0115^{* *} \\
(0.0027)\end{array}$ & $\begin{array}{l}0.0141^{* *} \\
(0.0028)\end{array}$ \\
\hline Tax loss carryforwards & $\begin{array}{l}0.01084^{*} \\
(0.0063)\end{array}$ & $\begin{array}{c}0.0056 \\
(0.0039)\end{array}$ & $\begin{array}{l}0.7373 * \\
(0.3988)\end{array}$ \\
\hline Investment tax credits & $\begin{array}{l}-3.2807 * * \\
(1.4920)\end{array}$ & $\begin{array}{l}-4.0179 * * \\
(0.8928\end{array}$ & $\begin{array}{l}-3.4707 * * \\
(0.9183)\end{array}$ \\
\hline Depreciation & $\begin{array}{l}-0.2839 * * \\
(0.0755)\end{array}$ & $\begin{array}{l}-0.2123^{* *} \\
(0.0455)\end{array}$ & $\begin{array}{l}-0.2668^{* *} \\
(0.0468)\end{array}$ \\
\hline $\begin{array}{l}\text { Investment tax credits * } \\
\text { bankruptcy predictor }\end{array}$ & $\begin{array}{c}0.2669 \\
(0.3400)\end{array}$ & $\begin{array}{c}0.8304 \\
(0.8604)\end{array}$ & $\begin{array}{c}0.3841 \\
(0.8850)\end{array}$ \\
\hline Bankruptcy predictor & $\begin{array}{l}-0.00091 \\
(0.0024)\end{array}$ & $\begin{array}{l}-0.2082 \\
(0.2190)\end{array}$ & $\begin{array}{c}-0.2668 \\
(-0.2252)\end{array}$ \\
\hline Current debt/total asset ratio & $\begin{array}{l}-0.2430 * * \\
(0.0337)\end{array}$ & $\begin{array}{l}-0.2759^{* *} \\
(0.0209)\end{array}$ & $\begin{array}{l}-0.2757^{* *} \\
(0.0214)\end{array}$ \\
\hline $\begin{array}{l}\text { Variance of earnings, } \\
\text { Type A }\end{array}$ & $\begin{array}{c}-0.3633^{* *} \\
(0.0773)\end{array}$ & $\begin{array}{l}-0.4556^{* *} \\
(0.0463)\end{array}$ & $\begin{array}{l}-0.4786 * * \\
(0.0476)\end{array}$ \\
\hline $\begin{array}{l}\text { Variance of earnings, } \\
\text { Type B }\end{array}$ & $\begin{array}{l}-0.1602 \\
(0.1238)\end{array}$ & $\begin{array}{l}-0.6207 \\
(0.7297)\end{array}$ & $\begin{array}{l}-0.8158 \\
(0.7506)\end{array}$ \\
\hline $\begin{array}{l}\text { Variance } A * \text { bankruptcy } \\
\text { predictor }\end{array}$ & $\begin{array}{l}0.00412 \\
(0.0126)\end{array}$ & $\begin{array}{c}0.1264 \\
(0.7297)\end{array}$ & $\begin{array}{c}0.1633 \\
(0.1564)\end{array}$ \\
\hline 1979 & 0.7008 & 0.6934 & 0.1077 \\
\hline 1981 & $-0.4170^{*}$ & -0.61 & -0.1363 \\
\hline 1982 & 0.6564 & 0.1159 & 0.1083 \\
\hline 1983 & 0.2163 & 0.2343 & 0.1095 \\
\hline 1984 & -0.1271 & -0.1398 & -0.1079 \\
\hline 1985 & -0.3215 & $-0.2196^{*}$ & -0.145 \\
\hline 1986 & 0.2486 & $-0.2226^{*}$ & -0.1024 \\
\hline 1987 & $-0.4371 * *$ & $-0.426 * *$ & $-0.3802 * *$ \\
\hline 1988 & $-0.6709 * *$ & & \\
\hline
\end{tabular}




\section{APPENDIX III (CONCLUDED). ADDITIONAL RESULTS FOR THE ESTIMATION OF EXPECTED TAX RATES}

\begin{tabular}{l|ccc}
\hline Variable & $\begin{array}{c}\text { Model II: One-Period } \\
\text { Ahead Tax Rates }\end{array}$ & $\begin{array}{c}\text { Model III: Unweighted } \\
\text { Five-Period Ahead Taxes }\end{array}$ & $\begin{array}{c}\text { Model IV: Weighted } \\
\text { Five-Period Ahead } \\
\text { Taxes }\end{array}$ \\
\hline 1989 & $-0.5718^{* *}$ & & \\
1990 & $-0.4771^{* *}$ & & \\
1991 & $-0.5632^{* *}$ & & $0.3403^{* *}$ \\
Constant & $0.3351^{* *}$ & $0.3377^{* *}$ & 8,361 \\
\hline n & 12,077 & 8,361 & \\
\hline
\end{tabular}

** significant at the 5 percent level.

* significant at the 10 percent level.

Note: Definitions and descriptive statistics are in Appendices I and II, respectively. Recall that Model I uses actual one-period ahead tax rates. Model II is a random effects model, estimated by feasible least squares; Models III and IV are estimated by two-factor fixed effects. Standard errors are in parentheses. 
APPENDIX IV. ADDITIONAL RESULTS FOR THE FINANCING DECISION

\begin{tabular}{|c|c|c|c|c|c|}
\hline & Variable & Model I & Model II & Model III & Model IV \\
\hline $\begin{array}{l}\text { Tax } \\
\text { hypothesis }\end{array}$ & Effective tax rates & $\begin{array}{l}0.004^{* *} \\
(0.002) \\
\end{array}$ & $\begin{array}{c}0.098^{* *} \\
(0.014) \\
\end{array}$ & $\begin{array}{c}0.163^{* *} \\
(0.019) \\
\end{array}$ & $\begin{array}{r}0.135^{* *} \\
(0.016) \\
\end{array}$ \\
\hline \multirow[t]{4}{*}{$\begin{array}{l}\text { Bankruptcy } \\
\text { costs }\end{array}$} & $\begin{array}{l}\text { Variance of earnings, } \\
\text { Type A }\end{array}$ & $\begin{array}{l}-0.120^{* *} \\
(0.027)\end{array}$ & $\begin{array}{c}-0.098^{* *} \\
(0.026)\end{array}$ & $\begin{array}{c}-0.063 * * \\
(0.024)\end{array}$ & $\begin{array}{c}-0.071^{* *} \\
(0.024)\end{array}$ \\
\hline & $\begin{array}{l}\text { Variance of earnings, } \\
\text { Type B }\end{array}$ & $\begin{array}{c}0.366 \\
(0.442)\end{array}$ & $\begin{array}{c}0.531 \\
(0.442)\end{array}$ & $\begin{array}{c}0.539 \\
(0.344)\end{array}$ & $\begin{array}{c}0.546 \\
(0.344)\end{array}$ \\
\hline & $\begin{array}{l}\text { Variance A * } \\
\text { Bankruptcy predictor }\end{array}$ & $\begin{array}{l}-0.003 \\
(0.004)\end{array}$ & $\begin{array}{l}-0.005 \\
(0.004)\end{array}$ & $\begin{array}{c}-0.019 * * \\
(0.007)\end{array}$ & $\begin{array}{c}-0.018^{* *} \\
(0.007)\end{array}$ \\
\hline & Bankruptcy predictor & $\begin{array}{c}0.0003 \\
(0.0008) \\
\end{array}$ & $\begin{array}{c}0.0008 \\
(0.0008) \\
\end{array}$ & $\begin{array}{c}0.002^{* *} \\
(0.001)\end{array}$ & $\begin{array}{r}0.002 * * \\
(0.001)\end{array}$ \\
\hline \multirow[t]{5}{*}{ Agency costs } & $\begin{array}{l}\text { Fraction of assets in } \\
\text { plant and equipment }\end{array}$ & $\begin{array}{c}0.002 \\
(0.004)\end{array}$ & $\begin{array}{l}0.006^{*} \\
(0.003)\end{array}$ & $\begin{array}{l}0.0005 \\
(0.003)\end{array}$ & $\begin{array}{l}0.0003 \\
(0.003)\end{array}$ \\
\hline & R\&D expenditures & $\begin{array}{c}0.121^{* *} \\
(0.056)\end{array}$ & $\begin{array}{l}0.139 * * \\
(0.048)\end{array}$ & $\begin{array}{l}0.074^{*} \\
(0.045)\end{array}$ & $\begin{array}{l}0.079 * \\
(0.045)\end{array}$ \\
\hline & $\begin{array}{l}\text { Advertising } \\
\text { expenditures }\end{array}$ & $\begin{array}{c}0.075 \\
(0.063)\end{array}$ & $\begin{array}{c}0.055 \\
(0.057)\end{array}$ & $\begin{array}{c}0.003 \\
(0.053)\end{array}$ & $\begin{array}{c}0.006 \\
(0.053)\end{array}$ \\
\hline & Free cash flow & $\begin{array}{l}0.0014 \\
(0.004)\end{array}$ & $\begin{array}{l}-0.0004 \\
(0.004)\end{array}$ & $\begin{array}{l}0.007^{*} \\
(0.004)\end{array}$ & $\begin{array}{l}0.007^{*} \\
(0.004)\end{array}$ \\
\hline & $\begin{array}{l}\text { Market value of } \\
\text { equity/book value }\end{array}$ & $\begin{array}{c}-0.223 \\
(0.186) \\
\end{array}$ & $\begin{array}{l}-0.239 \\
(0.185)\end{array}$ & $\begin{array}{c}-1.064^{* *} \\
(0.367)\end{array}$ & $\begin{array}{c}-1.069 * * \\
(0.367) \\
\end{array}$ \\
\hline \multirow[t]{2}{*}{ Signalling } & Change in stock price & $\begin{array}{l}0.233^{*} \\
(0.127)\end{array}$ & $\begin{array}{c}0.205 \\
(0.127)\end{array}$ & $\begin{array}{c}0.184 \\
(0.119)\end{array}$ & $\begin{array}{l}0.183 \\
(0.119)\end{array}$ \\
\hline & Dividend paying firm & $\begin{array}{l}0.02 * * \\
(0.005)\end{array}$ & $\begin{array}{c}0.015 * * \\
(0.005) \\
\end{array}$ & $\begin{array}{c}0.002 \\
(0.005)\end{array}$ & $\begin{array}{c}0.002 \\
(0.005) \\
\end{array}$ \\
\hline \multirow[t]{2}{*}{ Other } & Investment & $\begin{array}{c}0.084^{* *} \\
(0.009)\end{array}$ & $\begin{array}{l}0.09 * * \\
(0.009)\end{array}$ & $\begin{array}{l}0.073^{* *} \\
(0.008)\end{array}$ & $\begin{array}{c}0.072 * * \\
(0.008)\end{array}$ \\
\hline & Net assets & $\begin{array}{l}-0.238^{*} \\
(0.125)\end{array}$ & $\begin{array}{l}-0.178 \\
(0.123)\end{array}$ & $\begin{array}{c}-0.369^{*} \\
(0.2)\end{array}$ & $\begin{array}{c}-0.398 * * \\
(0.2)\end{array}$ \\
\hline
\end{tabular}




\section{APPENDIX IV (CONCLUDED). ADDITIONAL RESULTS FOR THE FINANCING DECISION}

\begin{tabular}{l|l|cccc}
\hline \multicolumn{2}{|c}{ Variable } & Model I & Model II & Model III & Model IV \\
\hline \multirow{2}{*}{ Retained earnings } & $0.017^{* *}$ & $0.01^{* *}$ & -0.002 & -0.001 \\
& & $(0.004)$ & $(0.004)$ & $(0.003)$ & $(0.003)$ \\
& \multirow{3}{*}{ Total assets } & $-0.156^{*}$ & 0.122 & -0.221 & -0.244 \\
& & $(0.093)$ & $(0.092)$ & $(0.155)$ & $(0.155)$ \\
\hline & & 12,077 & 12,077 & 8,361 & 8,361 \\
\hline
\end{tabular}

** significant at the 5 percent level.

*significant at the 10 percent level.

Note: Definitions and descriptive statistics are in Appendices I and II, respectively. The dependent variable is the change in debt divided by total assets. Two-factor fixed effects model. Fixed effects for firms and periods not reported. Standard errors are in parentheses. 


\section{REFERENCES}

Altman, E., 1968, "Financial Ratios, Discriminant Analysis, and the Prediction of Corporate Bankruptcy," Journal of Finance, Vol. 23, pp. 589-609.

Altshuler, R., and A. Auerbach, 1990, "The Significance of Tax Law Asymmetries: An Empirical Investigation," Quarterly Journal of Economics, pp. 61-86.

Auerbach, A., 1985, "Real Determinants of Corporate Leverage," in Corporate Capital Structures in the United States, ed. by B. Friedman (Chicago: University of Chicago Press), pp.125-43.

Auerbach, A., and J. Poterba, 1987, "Tax Loss Carryforwards and Corporate Tax Incentives," in The Effects of Taxation on Capital Accumulation, ed. by Martin S. Feldstein (Chicago: University of Chicago Press), pp. 305-37.

Bradley, M., G. Jarrell, and E. Kim, 1984, "On the Existence of an Optimal Capital Structure: Theory and Evidence," Journal of Finance, Vol. 39, pp. 857-78.

Fullerton, D., 1984, "The United States," in The Taxation of Income from Capital, ed. by M. King and D. Fullerton, pp. 193-267.

Gentry, W., 1994, "Taxes, Financial Decisions and Organizational Form: Evidence from Publicly Traded Partnerships," Journal of Public Economics, Vol. 53 (February), pp. 223-44.

Gropp, R., 1995, "Local Taxes and Capital Structure Choice" (mimeo; Washington: International Monetary Fund).

Holden, K., D. Peel, and J. Thomson, 1985, Expectations: Theory and Evidence (London: Macmillan).

Hsiao, C., 1986, Analysis of Panel Data (Cambridge, England: Cambridge University Press).

Jensen, M., 1986, “Agency Costs of Free Cash Flow, Corporate Finance, and Takeovers," American Economic Review, Vol. 76, pp. 323-29.

Jensen, M., and W. Meckling, 1976, "Theory of the Firm: Managerial Behavior, Agency Costs and Ownership Structure," Journal of Financial Economics, Vol. 3, pp. 305-60. 
Kennan, J., 1979, “The Estimation of Partial Adjustment Models with Rational Expectations," Econometrica, Vol. 47, No. 6 (November), pp. 1441-55.

Loderer, C., and D. Mauer, 1992, "Corporate Dividends and Seasoned Equity Issues: An Empirical Investigation," Journal of Finance, Vol. 47, No. 1 (March), pp. 201-25.

MacKie-Mason, J., 1990a, “Do Taxes Affect Corporate Financing Decisions?," Journal of Finance, pp. 1471-93.

- 1990b, "Do Firms Care Who Provides Their Financing?," in Asymmetric Information, Corporate Finance, and Investment, ed. by G. Hubbard (Chicago: University of Chicago Press), pp. 63-103.

Mauer, D., and A. Triantis, 1994, "Interactions of Corporate Financing and Investment Decisions," Journal of Finance, Vol. 49 (September), pp. 1253-77.

Myers, S., 1977, "Determinants of Corporate Borrowing," Journal of Financial Economics, Vol. 5, No. 2 (November), pp. 147-75.

— 1984, "The Capital Structure Puzzle," Journal of Finance, Vol. 39, pp. 572-92.

Myers, S., and N. Majluf, 1984, "Corporate Financing and Investment Decisions When Firms Have Information That Investors Do Not Have," Journal of Financial Economics, Vol. 13, pp. 187-221.

Poterba, J., 1992, "Why Didn't the Tax Reform Act of 1986 Raise Corporate Taxes?," in Tax Policy and the Economy, Vol. 6, pp. 43-58.

Titman, S., and R. Wessels, 1988, "The Determinants of Capital Structure Choice," Journal of Finance, pp. 1-19.

Warner, J., 1977, "Bankruptcy Costs: Some Evidence," Journal of Finance, pp. 239-76.

Zodrow, G., 1989, "On the "Traditional" and "New" Views of Dividend Taxation," National Tax Journal, Vol. 44, No. 2, pp. 497-509. 